\title{
Socioeconomic factors associated with antimicrobial resistance of Pseudomonas aeruginosa, Staphylococcus aureus, and Escherichia coli in Chilean hospitals (2008-2017)
}

\author{
Kasim Allel, ${ }^{1}$ Patricia García, ${ }^{2}$ Jaime Labarca, ${ }^{3}$ José M. Munita, ${ }^{4}$ Magdalena Rendic, ${ }^{5}$ Grupo \\ Colaborativo de Resistencia Bacteriana, ${ }^{6}$ and Eduardo A. Undurraga ${ }^{5}$
}

Suggested citation Allel K, García P, Labarca J, Munita JM, Rendic M; Grupo Colaborativo de Resistencia Bacteriana; et al. Socioeconomic factors associated with antimicrobial resistance of Pseudomonas aeruginosa, Staphylococcus aureus, and Escherichia coli in Chilean hospitals (2008-2017). Rev Panam Salud Publica. 2020;44:e30. https://doi.org/10.26633/RPSP.2020.30

ABSTRACT

Objective. To identify socioeconomic factors associated with antimicrobial resistance of Pseudomonas aeruginosa, Staphylococcus aureus, and Escherichia coli in Chilean hospitals (2008-2017).

Methods. We reviewed the scientific literature on socioeconomic factors associated with the emergence and dissemination of antimicrobial resistance. Using multivariate regression, we tested findings from the literature drawing from a longitudinal dataset on antimicrobial resistance from 41 major private and public hospitals and a nationally representative household survey in Chile (2008-2017). We estimated resistance rates for three priority antibiotic-bacterium pairs, as defined by the Organisation for Economic Co-operation and Development; i.e., imipenem and meropenem resistant $P$. aeruginosa, cloxacillin resistant $S$. aureus, and cefotaxime and ciprofloxacin resistant E. coli.

Results. Evidence from the literature review suggests poverty and material deprivation are important risk factors for the emergence and transmission of antimicrobial resistance. Most studies found that worse socioeconomic indicators were associated with higher rates of antimicrobial resistance. Our analysis showed an overall antimicrobial resistance rate of $32.5 \%$, with the highest rates for S. aureus (40.6\%) and the lowest for E. coli (25.7\%). We found a small but consistent negative association between socioeconomic factors (income, education, and occupation) and overall antimicrobial resistance in univariate $(p<0.01)$ and multivariate analyses $(p<0.01)$, driven by resistant $P$. aeruginosa and $S$. aureus.

Conclusion. Socioeconomic factors beyond health care and hospital settings may affect the emergence and dissemination of antimicrobial resistance. Preventing and controlling antimicrobial resistance requires efforts above and beyond reducing antibiotic consumption.

Keywords Drug resistance, microbial; antibacterial agents; social conditions; social determinants of health; Latin America.

\footnotetext{
1 Millennium Initiative for Collaborative Research in Bacterial Resistance (MICROB-R), Santiago, Chile

2 Departamento de Laboratorios Clínicos, Escuela de Medicina, Facultad de Medicina, Pontificia Universidad Católica de Chile, Santiago, Chile

3 Departamento de Enfermedades Infecciosas, Escuela de Medicina, Facultad de Medicina, Pontificia Universidad Católica de Chile, Santiago, Chile
}

\footnotetext{
4 Facultad de Medicina Clínica Alemana, Universidad del Desarrollo, Las Condes, Chile

5 Escuela de Gobierno, Pontificia Universidad Católica de Chile, Santiago, Chile. $\triangle$ Eduardo A. Undurraga, eundurra@uc.cl

6 Grupo Colaborativo de Resistencia Bacteriana de la Sociedad Chilena de Infectología, Chile
} 
The emergence and spread of antimicrobial resistance is one of the most urgent global public health threats $(1,2)$. Infections caused by resistant bacteria produce greater morbidity and mortality, complicate treatments, and often result in longer hospitalizations, imposing higher costs to health systems $(2,3)$. Antimicrobial resistance occurs naturally as an adaptive mechanism of bacteria; global increases in antibiotic use in humans, animals (e.g., food production), and agriculture (e.g., use of copper as a bactericide), have increased the selective pressure that drives the development of resistance, dramatically accelerating this natural phenomenon (4-6). A recent estimate for 76 countries by Klein et al. (7) shows overall antibiotic consumption, in defined daily doses (DDD), increased about $65 \%$ and antibiotic consumption rate (DDDs per 1000 inhabitants per day) increased about 39\% between 2000 and 2015. This increase in antibiotic consumption was largely driven by lowand middle-income countries (7).

Although frequently overlooked, the emergence and dissemination of antimicrobial resistance is also affected by socioeconomic and environmental factors, including inadequate water, sanitation, and hygiene (WASH) infrastructure, living conditions, waste management, education and awareness, economic activities, and other factors such as climate, health care quality, and migration (8-12). In addition, the lack of incentives has limited the development of new antibiotics; the process is expensive and expected profits are limited compared to other medications, largely because the clinical benefits of antibiotics decrease in time and their use needs to be restricted to prevent resistance (13).

Recent estimates indicate that antimicrobial resistance in Latin American countries ranges from $21 \%$ in Chile to $40 \%$ in Brazil, in contrast to an average antimicrobial resistance rate of $17 \%$ for countries from the Organisation for Economic Co-operation and Development (OECD) (14). Socioeconomic factors could be important predictors of antimicrobial resistance spread in Latin America, a region with several competing health priorities, limited health resources, deficient WASH infrastructure, uneven health care access, South-South migration, extreme poverty, a large food industry, and ubiquitous economic inequality $(15,16)$.

The objective of our study was to identify socioeconomic factors associated with imipenem and meropenem resistant Pseudomonas aeruginosa, cloxacillin resistant Staphylococcus aureus, and cefotaxime and ciprofloxacin resistant Escherichia coli in Chilean hospitals (2008-2017).

\section{MATERIALS AND METHODS}

\section{Literature review}

We searched for articles on antimicrobial resistance and socioeconomic factors in PubMed combining the keywords antibiotic resistance OR resistant bacteria with each of the following key-terms: "socioeconomic" OR "poverty" OR "water, sanitation, and hygiene" OR "WASH" OR "slum" for years 2000 through August 2019, in any language. We restricted the search to NOT "HIV" OR "AIDS" OR "tuberculosis" OR "TB" OR "virus" OR "fungus" OR "parasites" OR "malaria" OR "parasitic diseases." We included all articles with empirical data or literature reviews, full-text available, scientifically valid approach, and external validity. We also looked for additional records in the references of the articles that qualified for our qualitative synthesis, and included articles from our research on antimicrobial resistance (e.g., not indexed, book chapters, government reports, policy briefs). We excluded editorials, qualitative reports, opinions, and duplicated studies. Last, we only considered articles related to antimicrobial resistance in general, or those that included the following bacteria: P. aeruginosa, S. aureus, and E. coli.

\section{Empirical analysis: Chile as a case study}

We combined two datasets. We used antimicrobial resistance rates from 41 tertiary care hospitals (i.e., high complexity) in Chile, and socioeconomic data from the Encuesta de Caracterización Socioeconómica Nacional (CASEN). More specifically, antimicrobial resistance data were collected annually (20082017) by the Grupo Colaborativo de Resistencia Bacteriana (GCRB) from the Chilean Society of Infectious Diseases (17); data include $67 \%$ of public and private tertiary hospitals in Chile. The GCRB hospital network began with 19 hospitals in 2008 and has increased in size, to more than 50 hospitals in 2019. We included observations from all hospitals reporting at least one observation (resistance rate) over time for each antibiotic-bacterium pair considered in our analysis $(n=41)$. For comparability, we estimated resistance proportions based on three OECD-defined priority antibiotic-bacterium pairs in 2015 , i.e., cefotaxime and ciprofloxacin resistant $E$. coli; cloxacillin resistant $S$. aureus; and imipenem and meropenem resistant $P$. aeruginosa (14). GCRB is an unbalanced panel; on average, hospitals reported 4.6 years of antimicrobial resistance data between 2008 and $2017(n=190)$ in 24 municipalities in Chile. GCRB is a collaborative clinical surveillance network; participant hospitals annually report the average susceptibility of a series of antibiotic-bacterium pairs from clinical samples, following Clinical and Laboratory Standards Institute (CLSI) recommendations $(17,18)$. Antibiotic resistance rates were calculated by dividing the number of laboratory tests that showed bacterial resistance to antibiotics by the total number of tests.

We characterized the population attended by hospitals at the municipality level, based on the CASEN survey for 20082017. CASEN is a nationally representative household survey, applied every two or three years since 1985 by the Chilean Ministry of Social Development, to socioeconomically characterize households. With an emphasis on poverty and social vulnerability, CASEN collects data on education, health, housing, work, and income. We standardized sociodemographic variables from CASEN by subtracting the overall mean and dividing by the overall standard deviation (SD) (8). Because we only had a limited number of annual observations for 41 hospitals in 24 municipalities, we reduced the number of covariates in the regressions to avoid overfitting. We created two sociodemographic indexes based on the expected characteristics of the population served by hospitals, aggregated at the municipality level. First, we created a household infrastructure index to characterize people's living conditions that may affect the spread of resistant bacteria (19-22), based on a household's poverty rate, sanitation, overcrowding, and material deprivation. Second, we created a socioeconomic status index, which aims to reflect economic activity, behavioral practices, and occupation of the population, composed of education level, income per capita, and occupation at the municipality level. Both indexes were standardized for the analysis ( mean $=0, S D=1$ ). Table 1 shows 
TABLE 1. Descriptive statistics for antibiotic resistance rates and socioeconomic factors associated with its emergence and dissemination in Chile, 2008-2017

\begin{tabular}{|c|c|c|c|c|}
\hline Variables & Mean & SD & IQR & Definition \\
\hline \multicolumn{5}{|l|}{ Antimicrobial resistance } \\
\hline Overall $(\%)$ & 32.5 & 0.09 & $12.9 \%$ & Average of three antibiotic-bacterium pairs, as described below \\
\hline P. aeruginosa $(\%)$ & 33.3 & 0.12 & $15.4 \%$ & Proportion of imipenem and meropenem resistant $P$. aeruginosa \\
\hline E. coli $(\%)$ & 25.7 & 0.09 & $11.4 \%$ & Proportion of cefotaxime and ciprofloxacin resistant E. coli \\
\hline S. aureus (\%) & 40.6 & 0.18 & $26.1 \%$ & Proportion of cloxacillin resistant $S$. aureus \\
\hline \multicolumn{5}{|c|}{ Household infrastructure index ${ }^{a}$} \\
\hline Poverty $(\%)$ & 10.2 & 0.06 & $9.8 \%$ & Population with income per capita below the poverty line ( US\$ 180 in 2017) \\
\hline Inadequate sanitation (\%) & 2.4 & 0.02 & $1.6 \%$ & $\begin{array}{l}\text { Population with inadequate sanitation (House Sanitation Index). Inadequate sanitation }(=1) \text { defined as } \\
\text { household with no access to drinkable water, or toilet or latrine not connected to the sewer or septic tank }\end{array}$ \\
\hline Material deprivation (\%) & 11.6 & 0.07 & $11.7 \%$ & $\begin{array}{l}\text { Population living in poor quality housing. Material deprivation }(=1) \text { defined as housing of reused materials } \\
\text { or a hut, tent, mobile home, or similar. }\end{array}$ \\
\hline Overcrowding $(\%)$ & 10.8 & 0.06 & $10.1 \%$ & People living in an overcrowded household defined as people/rooms $>2.4$ \\
\hline \multicolumn{5}{|l|}{ Socioeconomic index ${ }^{a}$} \\
\hline Income per capita (\$1 000 CLP) & 435 & 289 & 229 & Average income per capita, in 2017 CLP (Chilean pesos; 1 US\$ = CLP 700) \\
\hline Years of schooling & 12.5 & 1.7 & 2.2 & Average years of schooling for adult population ( $\geq 18$ years of age) \\
\hline Occupation index (ISCO) & 5.2 & 1.0 & 1.1 & $\begin{array}{l}\text { Continuous variable (1-9), representing average ISCO codes for occupations classification. Higher scores } \\
\text { represent high skilled occupations }\end{array}$ \\
\hline
\end{tabular}

Notes. SD: standard deviation; IQR: interquartile range. IQR $=75^{\text {th }}$ percentile $-25^{\text {th }}$ percentile. Hospitals in the sample are located in 26 municipalities, in 11 regions of Chile. a: These variables were obtained from the CASEN survey for years 2006, 2009, 2011, 2013, 2015, and 2017. Table prepared by authors.

variable definitions and descriptive statistics (further information is available from the authors by request).

We first examined descriptive statistics in our study sample. We plotted antimicrobial resistance rates for P. aeruginosa, $S$. aureus, and E. coli, and household infrastructure and socioeconomic status indexes in the regions of Chile for which hospital data were available. We then examined the bivariate correlation between antimicrobial resistance and sociodemographic characteristics of the population both graphically and using Pearson's test. Last, we ran linear regression models using pooled data to assess the association between antimicrobial resistance rates and socioeconomic status and household infrastructure, using year fixed effects, clustering of standard errors by hospital, and bootstrapping (random sampling with replacement) with 50 repetitions to make inferences about the population.

\section{RESULTS}

\section{Literature review}

We identified 145 published articles related to antimicrobial resistance and socioeconomic variables. Of these, 40 articles satisfied our inclusion and exclusion criteria. The main findings are summarized below.

Socioeconomic factors affecting antimicrobial resistance globally. Socioeconomic factors generally reflect people's living conditions, social status, and economic activities. These living conditions include overcrowded households, material deprivation, and inadequate access to WASH. Other related factors in the literature refer to years of schooling, income per capita, occupation, and various types of wealth. Social and economic disparities are also important because they may determine differential exposure to infectious diseases, including antimicrobial resistance, and differential access to and quality of health care $(6,8,10-12,20,23,24)$.

Research suggests poverty and material deprivation are important risk factors for the emergence and transmission of antimicrobial resistance $(6,12,19,21,23)$. Plausible mechanisms to explain this association include limited access to professional health care, inadequate hygiene, overcrowded households, deficient management of residuals, a higher burden of malnutrition, and limited access to drinkable water. Compared to high-income countries, antibiotics may also be of lower quality in lower-income countries, possibly because antibiotics are affected by weather conditions, such as humidity and temperature, and storage conditions may not be adequately regulated and supervised, resulting in degraded medications (25). Previous studies have also found substantial disparities on antimicrobial resistance by socioeconomic characteristics within and between countries (12). The development of antimicrobial resistance in low- and middle-income countries has been accelerated by poor regulation, self-medication, inadequate nosocomial infection control, inadequate epidemiological surveillance, clinical misuse, and deficient quality of antibiotics $(5,7,13,20)$. Previous studies $(21,26)$ suggest that people from deprived areas or low educational background have a higher likelihood of self-medication, favoring the emergence of antimicrobial resistance. The main driver of antimicrobial resistance in high-income countries is excess antibiotic use, including reserve use antibiotics, partly due to inadequate hospital regulation (27). On the other hand, in low- and middle-income countries antimicrobial resistance rates are largely driven by poor governance and sanitation, limited access to professional health care, insufficient WASH infrastructure, and self-medication (8).

Despite suggestive evidence, there is no closure over the association between low socioeconomic status and antimicrobial resistance. For instance, two studies, in Indonesia and India, found that people living in poorer or overcrowded households had a lower probability of having resistant E. coli. This finding could be partially explained by limited or null access to antibiotics, and because overcrowding in the south of India may also occur in relatively high-income households $(28,29)$.

Socioeconomic status may be driving antimicrobial resistance rates in Latin America. Only a handful of studies have examined the association between antimicrobial resistance 
and socioeconomic factors in Latin America, specifically, in Brazil (22), Argentina (30), Mexico (31), Bolivia (32), and Peru (24). A study in Osasco (Brazil) collected stool samples from 79 children aged 5-10 years in a slum, to analyze the presence of diarrheagenic E. coli. Results showed $58 \%$ were positive for E. coli, of which $65 \%$ were resistant to at least one antibiotic (22). Similarly, researchers analyzed 591 clinical isolates of S. aureus recovered from 66 different hospitals in Argentina. The study suggested patients infected with drug-resistant $S$. aureus were more likely to come from low-income, overcrowded households, and had less years of schooling (30). A study in Mexico found $75 \%$ of the $158 \mathrm{P}$. aeruginosa isolates from three public hospitals in Mexico City were resistant to at least one antibiotic (31). In Bolivia, a study in a rural area with high poverty rates examined 213 isolates, of which 170 were E. coli isolates with $74 \%$ of the sample resistant to trimethoprim-sulfamethoxazole (32). In contrast, a study in two Amazonian communities in Peru found that children from wealthier families were more likely to have antimicrobial resistant E. coli (24). Interestingly, the authors noted that antibiotic consumption was not apparently driving the association of wealth and antimicrobial resistance. Overall, most studies suggest that worse socioeconomic indicators are associated with higher rates of antimicrobial resistance.

\section{Empirical analysis: the case of Chile}

Descriptive statistics. Table 1 shows that the overall antimicrobial resistance rate was $32.5 \%$ for our sample of hospitals, with the highest for $S$. aureus $(40.6 \%, \mathrm{SD}=0.18)$, and the lowest antimicrobial resistance for E. coli $(25.7 \%, \mathrm{SD}=0.09)$. The interquartile ranges (IQR), suggest there was a relatively lower variation in antimicrobial resistance for E. coli across hospitals $(11.4 \%)$, compared to S. aureus $(26.1 \%)$ and P. aeruginosa $(15.4 \%)$. Socioeconomic factors among the population in municipalities with tertiary hospitals included in the sample show relatively low rates of poverty $(10.2 \%, \mathrm{SD}=0.06)$, few households with inadequate sanitation $(2.4 \%, \mathrm{SD}=0.02)$, and an average of 12 years of schooling $(\mathrm{SD}=1.7)$.

Fig. 1 shows how socioeconomic status, household infrastructure, and antimicrobial resistance rates are distributed by region in Chile. Colors represent quartiles in the average values for each variable across all years in the sample, with lighter colors representing a more desirable situation. The distribution suggests relatively better socioeconomic indicators (Fig. 1, panels A and B) are found in northern regions, Región Metropolitana, and Región de Magallanes. Interestingly, Fig. 1, panel C, suggests overall antimicrobial resistance rates are higher in Región de Los Lagos, particularly for $P$. aeruginosa (Fig. 1, panel F). Regions in central and southern Chile show a more consistent correlation between worse socioeconomic status and household infrastructure indexes and higher antimicrobial resistance rates. Fig. 1 also shows higher antimicrobial resistance rates in northern regions, particularly for S. aureus (panels C and D).

Univariate analysis. Fig. 2 shows the Pearson bivariate correlation level (ranging from -1 to 1 ) between antimicrobial

FIGURE 1. Distribution of socioeconomic status, household infrastructure index and antimicrobial resistance rates by region in Chile, 2008-2017

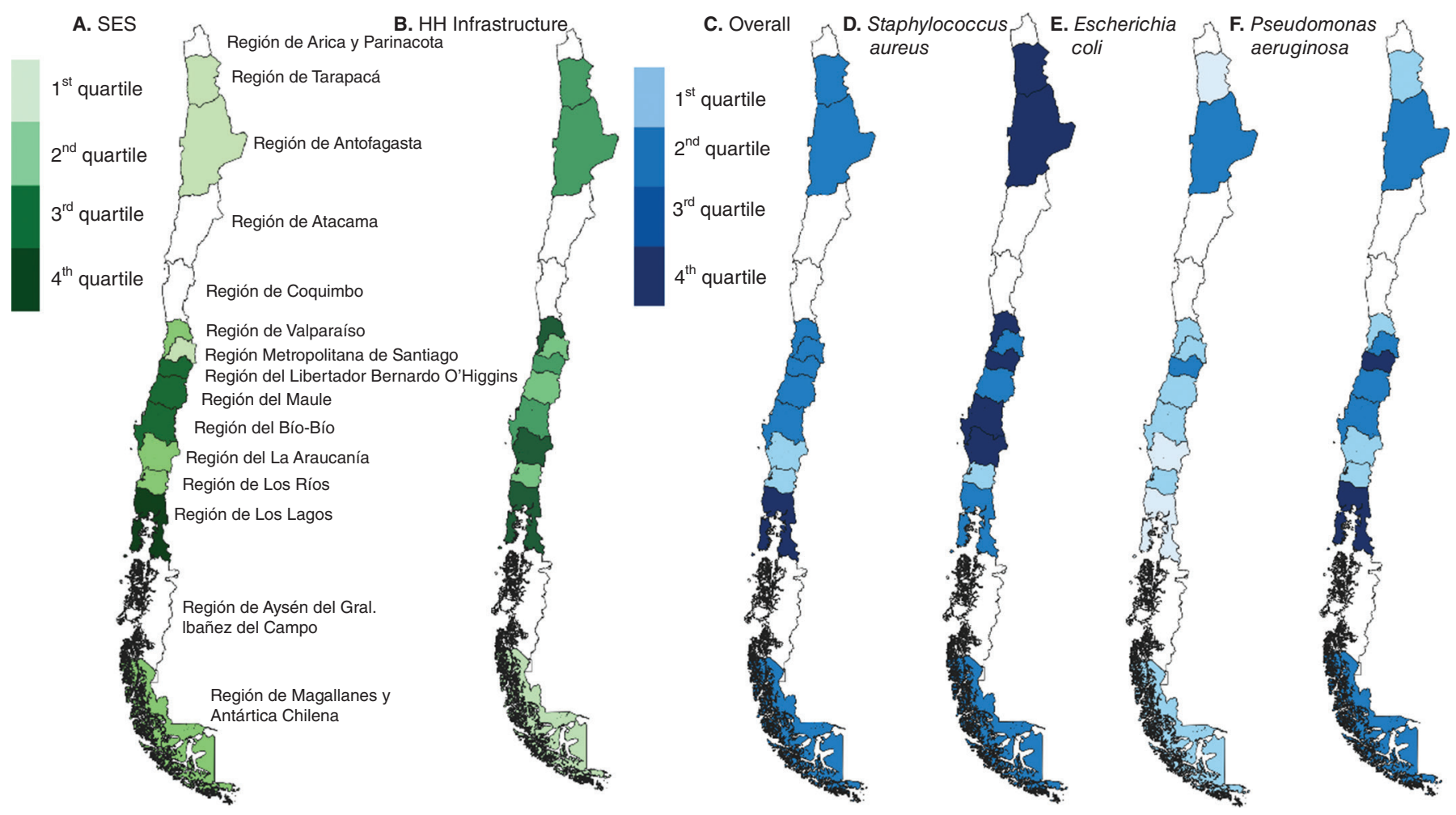

Notes. Maps A and B show the distribution of socioeconomic status (SES) and household (HH) infrastructure indexes respectively by quartiles. Maps C, D, E, and F show overall antimicrobial resistance rates fo S. aureus, E. coli, and P. aeruginosa, and then for each bacterium separately based on OECD standards and specifications (14). Antimicrobial resistance rates range from 0-18\%, 18-28\%, 28-40\%, and $+40 \%$ for each quartile, respectively. White areas display regions with no available data. The $1^{\text {st }}$ quartile presents the best socioeconomic and antimicrobial resistance scenario. Figure prepared by authors. 
resistance and several social and economic factors included in our data. Negative values are shown in red and positive values in blue. We found a consistent negative association between socioeconomic status factors (income, education, and occupation) and overall antimicrobial resistance rate, with large correlations for P. aeruginosa $(\mathrm{r}=0.62, \mathrm{p}<0.001)$ and $S$. aureus $(\mathrm{r}=0.84, \mathrm{p}=0.01)$. We found a positive correlation between $P$. aeruginosa resistance rates and inadequate sanitation $(r=0.44$, $p=0.02)$, and a weaker correlation between $S$. aureus resistance and income $(\mathrm{r}=-0.19, \mathrm{p}=0.1)$. Last, Fig. 2 suggests an unexpected correlation between E. coli resistance and socioeconomic factors (socioeconomic status and household infrastructure) possibly explained by the small observed variation in antimicrobial resistance of $E$. coli within hospitals $(\mathrm{r}=0.57, \mathrm{p}=0.01$; $\mathrm{r}=-0.45, \mathrm{p}=0.01$, respectively). Values between -0.1 and 0.1 were not significant $(\alpha=10 \%)$.
Fig. 3 suggests the median overall resistance rate for E. coli, $S$. aureus, and P. aeruginosa does not show significant variation, with rates around $28 \%$ to $38 \%$, and a slight decrease from 2009 to 2017 ( $p<0.001$, see Fig. 3, panel A). E. coli rates have remained relatively constant across years (Fig. 3, panel B). Resistance rates of $P$. aeruginosa show some variation over the years, but also show the smallest variation across hospitals in the sample. Finally, S. aureus resistance rates have substantially decreased from $2009(\sim 68 \%)$ to $2017(\sim 38 \%)$.

Multivariate analysis. Table 2, model 1, shows a negative association of socioeconomic status index and overall antimicrobial resistance rate $(\beta=-0.01$, standard error $(\mathrm{se})=0.00$, $\mathrm{p}=0.06$ ), which suggests one SD increase in the socioeconomic status index is associated with a $1 \%$ decrease in antimicrobial resistance. This statistically significant association was similar for $P$. aeruginosa (Table 2 , model $2, \beta=-0.01$, se $=0.00, \mathrm{p}<0.001$ ),

FIGURE 2. Pearson correlations of antibiotic resistance rates of $E$. coli, S. aureus, and $P$. aeruginosa and socioeconomic factors in Chile, 2008-2017

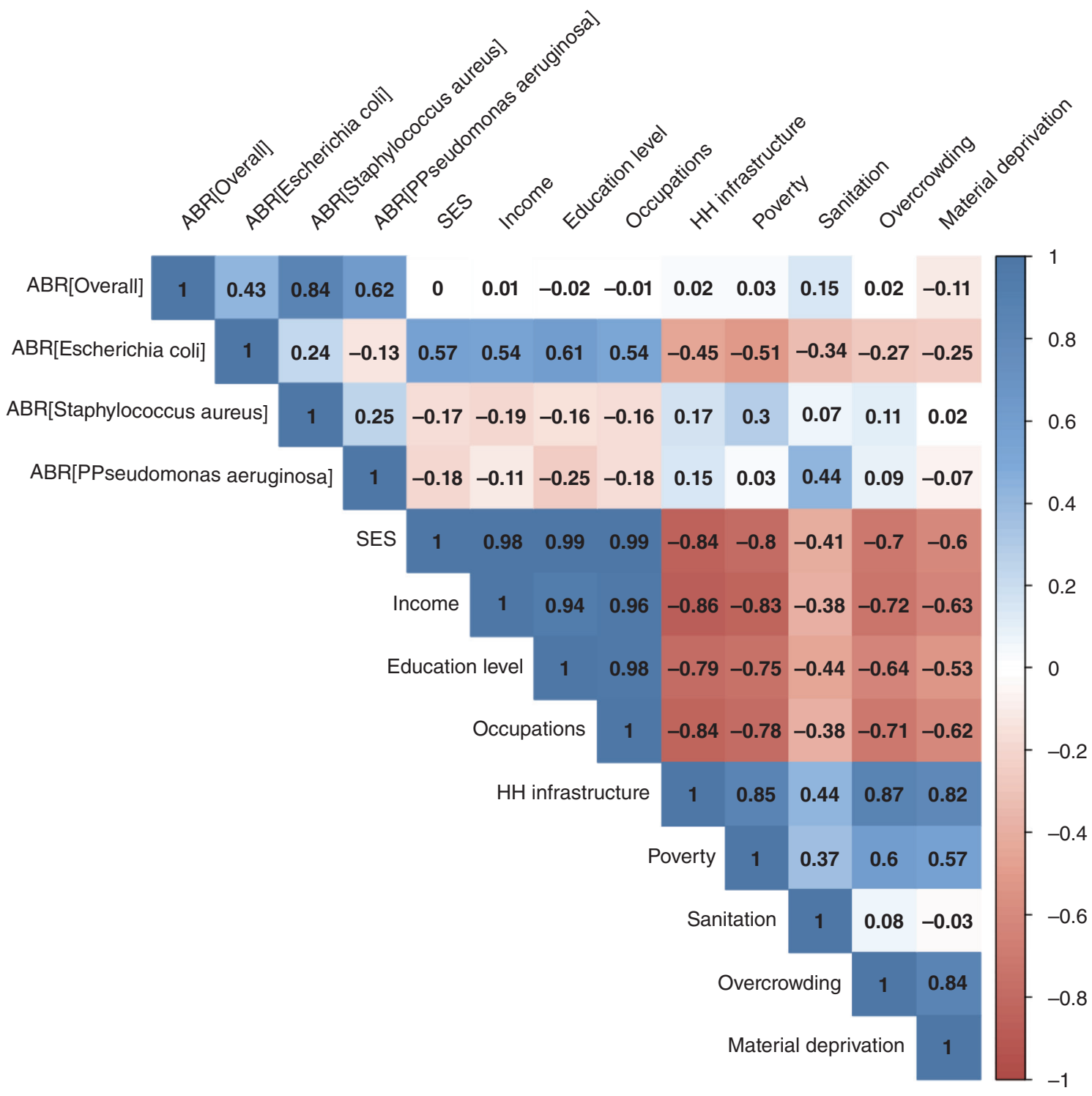

Notes. Red colors represent negative relation, while blue colors display positive relations. Lighter blocks represent no significant correlation $(p<0.10)$. Figure prepared by authors. ABR stands for antibiotic or antimicrobial resistance rates, which were calculated based on OECD standards. Antibiotic-bacterium pairs are cefotaxime and ciprofloxacin resistant $E$. coli, imipenem and meropenem resistant $P$. aeruginosa, and 
FIGURE 3. Evolution of the proportion of antimicrobial resistant bacteria for (A) all bacteria in the sample, (B) cefotaxime and ciprofloxacin resistant $E$. coli, (C) imipenem and meropenem resistant $P$. aeruginosa, and (D) cloxacillin resistant $S$. aureus in 41 hospitals in Chile, 2008-2017
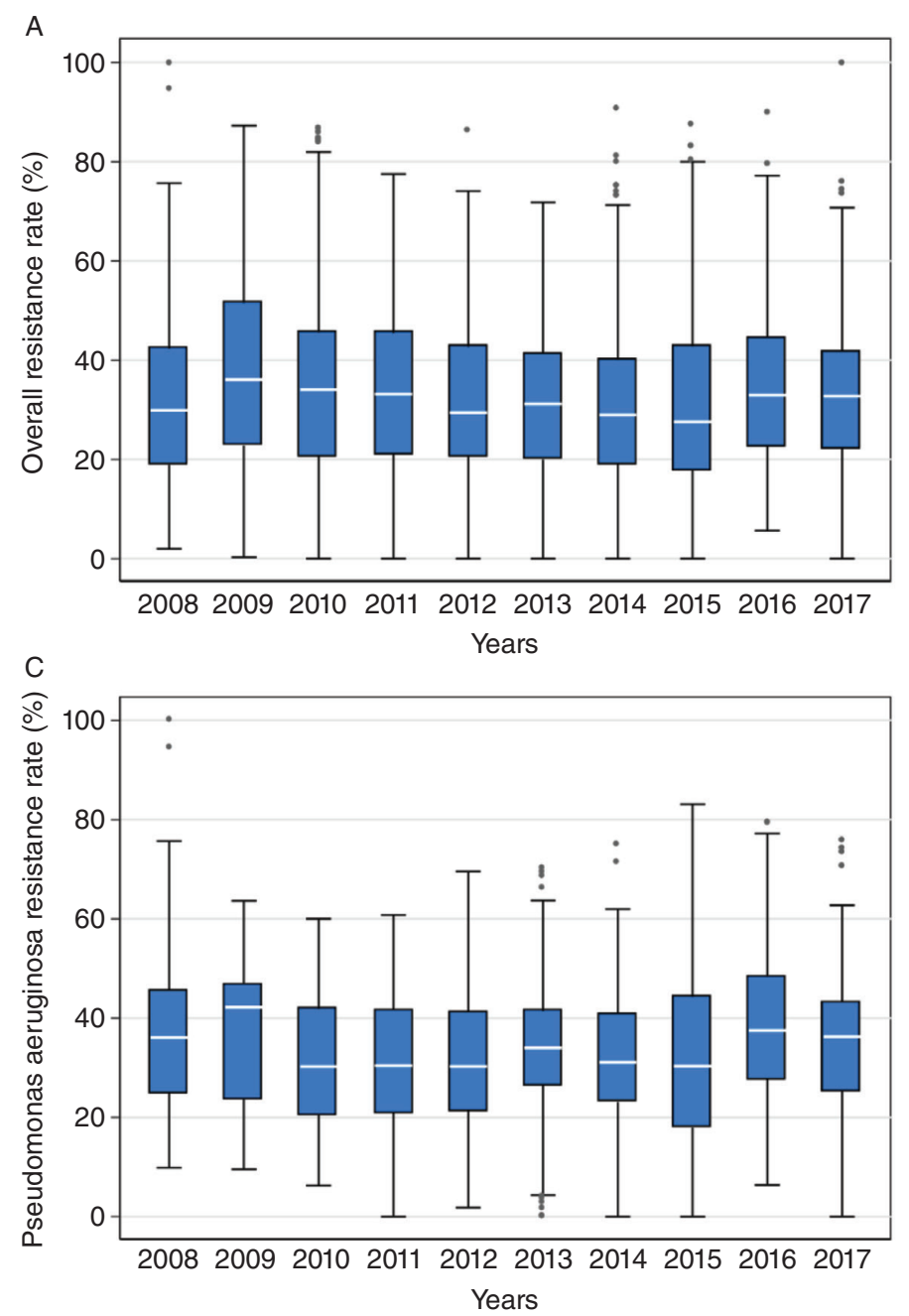

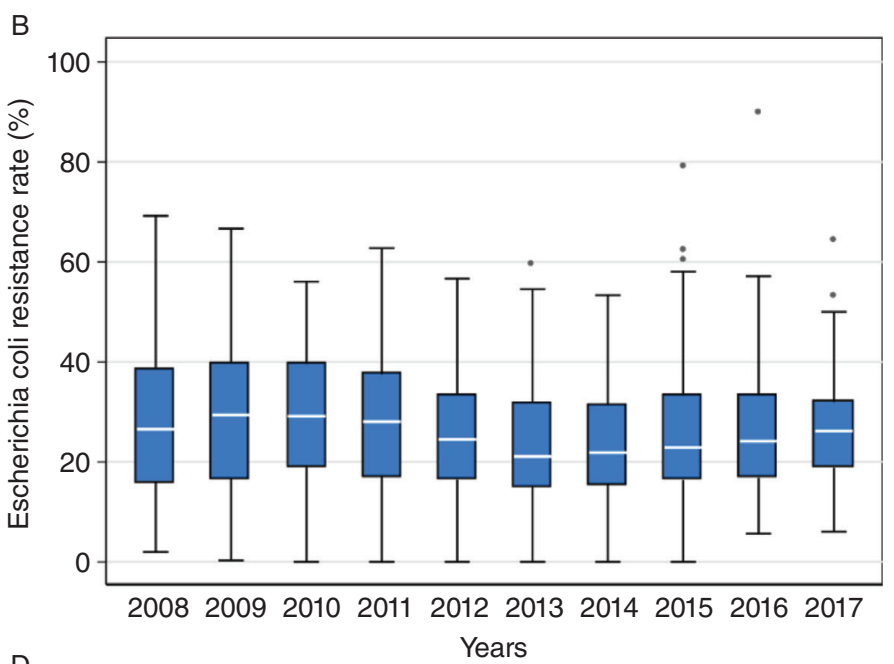

D

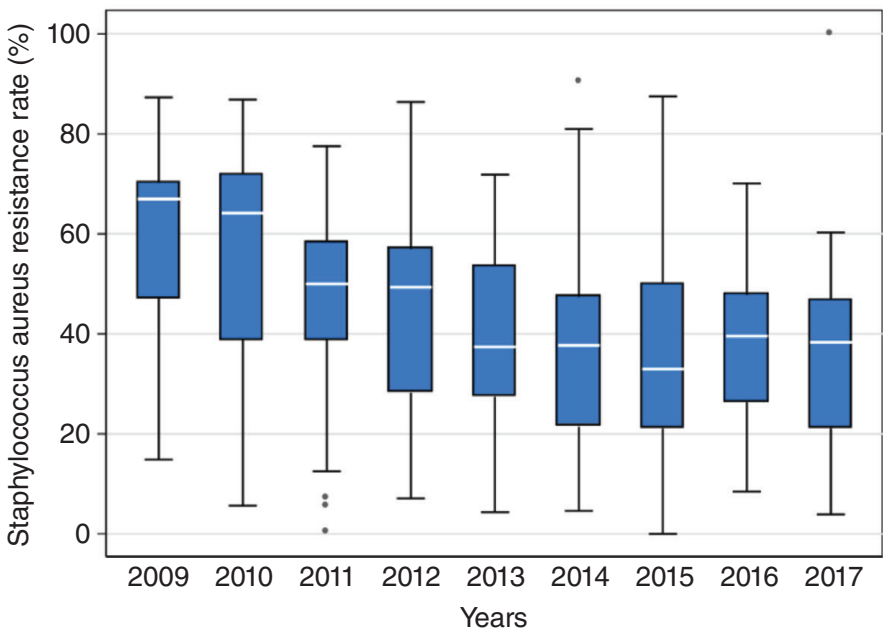

Notes. E. coli, S. aureus, and P. aeruginosa. Resistance rates are calculated as 1-Susceptibility rate. White lines indicate the median rate. Circle markers stand for outliers. Figure prepared by authors. Antimicrobial resistance rates were calculated based on OECD standards.

TABLE 2. Linear regression of antimicrobial resistance rates for E. coli, S. aureus, and $P$. aeruginosa against household infrastructure and socioeconomic status indexes, pooled data analysis for 41 hospitals in Chile, 2008-2017

\begin{tabular}{|c|c|c|c|c|c|c|c|c|}
\hline \multirow{3}{*}{$\begin{array}{l}\text { Outcome: } \\
\text { Overall rate }\end{array}$} & \multirow{2}{*}{\multicolumn{2}{|c|}{$\begin{array}{l}\text { Model } 1 \\
\text { Overall rate }\end{array}$}} & \multirow{2}{*}{\multicolumn{2}{|c|}{$\begin{array}{c}\text { Model } 2 \\
\text { P. aeruginosa }\end{array}$}} & \multirow{2}{*}{\multicolumn{2}{|c|}{$\begin{array}{c}\text { Model } 3 \\
\text { E. coli }\end{array}$}} & \multirow{2}{*}{\multicolumn{2}{|c|}{$\begin{array}{l}\text { Model } 4 \\
\text { S. aureus }\end{array}$}} \\
\hline & & & & & & & & \\
\hline & $\beta$ & se & $\beta$ & se & $\beta$ & se & $\beta$ & se \\
\hline $\begin{array}{l}\text { Household } \\
\text { infrastructure }\end{array}$ & 0.00 & 0.00 & 0.00 & 0.00 & 0.00 & 0.00 & $-0.01^{* *}$ & 0.01 \\
\hline $\begin{array}{l}\text { Socioeconomic } \\
\text { status }\end{array}$ & $-0.01^{*}$ & 0.00 & $-0.01^{\star \star *}$ & 0.00 & $0.03^{\star *}$ & 0.00 & $-0.04^{\star \star \star}$ & 0.01 \\
\hline Constant & $0.40^{* * *}$ & 0.01 & $0.39 * * *$ & 0.01 & $0.30^{\star \star \star}$ & 0.01 & $0.60^{\star * *}$ & 0.02 \\
\hline $\begin{array}{l}\text { Number of } \\
\text { observations }\end{array}$ & 190 & & 190 & & 190 & & 190 & \\
\hline$R^{2}$ & $6 \%$ & & $6 \%$ & & $16 \%$ & & $18 \%$ & \\
\hline
\end{tabular}

Notes. se $=$ standard error. ${ }^{*} p<0.1,{ }^{* *} p<0.05$, and ${ }^{* * *} p<0.01$. Hospitals were observed with an average of 4.6 years between 2008 and 2017. All regressions include year fixed-effects, clustering of standard errors by hospital, and bootstrapping (random sampling with replacement) with 50 repetitions. Table prepared by authors. Antimicrobial resistance rates were calculated based on $O E C D$ standards and specifications. and four times larger for $S$. aureus (Table 2, model $4, \beta=-0.04$, $\mathrm{se}=0.01, \mathrm{p}<0.001)$. We found evidence of a positive statistically significant association between E. coli and socioeconomic factors $(\beta=0.03, \mathrm{p}=0.04)$, and a negative association between the household infrastructure index and $S$. aureus $(\beta=-0.01$, se $=$ $0.01, \mathrm{p}=0.03)$.

\section{DISCUSSION}

We have examined the association between social and economic factors and antimicrobial resistance rates for P. aeruginosa, S. aureus, and E. coli, through a literature review in PubMed and an empirical analysis in 41 hospitals in Chile for 2008-2017. Consistent with previous reviews $(6,12,19,21,23)$, we found that poverty and material deprivation may be important risk factors for antimicrobial resistance transmission. This association is probably explained by limited access to professional health care, inadequate WASH infrastructure, overcrowded 
households, and limited education (22). We found a significant partial correlation for an index of socioeconomic status (income, schooling, and occupation) and overall antimicrobial resistance, and S. aureus and P. aeruginosa resistance, consistent with previous literature (30). We did not find much evidence of a significant association between antimicrobial resistance and an index of household infrastructure, possibly due to the low variation of this index across municipalities and a relatively small sample size. A very large proportion of the population in Chile has access to adequate sanitation infrastructure, and compared to other countries in the region, Chile has relatively low poverty, overcrowding, and material deprivation rates.

Antimicrobial resistance is a relevant public health challenge in many countries of Latin America $(1,3,7,14,19,22)$. For instance, the OECD estimates resistance rates $\geq 30 \%$ for eight priority antibiotic-bacterium pairs in Argentina, Brazil, Colombia, Costa Rica, Mexico, and Peru (14). Klein et al. (7) estimated increases in national antibiotic consumption rates between 2002 and 2015 (DDDs per 1000 inhabitants per day) for all countries in Latin America and the Caribbean where data were available, except for Mexico. But beyond antibiotic consumption, antimicrobial resistance could worsen because of a relatively large proportion of the population living in poverty, many of whom lack adequate WASH infrastructure, and have limited access to professional health care and formal education $(6,8,15)$.

The results for our empirical analysis in Chile showed an overall $32.5 \%$ antimicrobial resistance rate for all three bacteria analyzed, six percentage points over recent estimates $(26.5 \%)$ published by the OECD (14). Specifically, we found resistance rates of $33.3 \%$ for P. aeruginosa, $25.7 \%$ for E. coli, and $40.6 \%$ for S. aureus, compared to OECD (14) estimates of $25.1 \%, 28.1 \%$, and $26.4 \%$, respectively. Our results provide, for the first time, national and subnational estimates of antimicrobial resistance for three clinically relevant antibiotic-bacterium pairs using a large longitudinal dataset of 41 hospitals in Chile, their geographical distribution in Chile, and also the evolution of resistance rates in the past decade (2008-2017). Rigorous and comparable estimates of antimicrobial resistance are essential to inform policy-making, define research and funding priorities, and evaluate stewardship programs and interventions.

Our analysis also showed a consistent negative association between socioeconomic status factors (income, education, and occupation) and overall antimicrobial resistance rate, with large correlations for $P$. aeruginosa and $S$. aureus, consistent with previous literature $(6,8,10-12,20,23,24)$. There is sparse literature on this topic globally, and only a handful of studies in Latin America. Our findings in Chile provide external validity to previous studies, and highlight the importance of factors associated with social and material living conditions that may help control this emerging public health crisis.

The multivariate model showed a relatively small but statistically significant association between socioeconomic status and antimicrobial resistance rates (specifically for P. aeruginosa and $S$. aureus). Unfortunately, we lack the data to test for settingspecific factors or transmission mechanisms. Resistant $S$. aureus, common in the nose and skin, has been associated with lack of adequate housing or homelessness, with transmission probably occurring in the communities (33). P. aeruginosa is ubiquitous in the environment and frequently found in streams and ponds; however, most documented infections are nosocomial. But there is at least some evidence that environmental conditions may favor $P$. aeruginosa infections in developing countries (34), perhaps related to a lack of running water. We found no evidence of correlation with E. coli, which is also frequently linked to inadequate WASH infrastructure. The bivariate analysis showed very consistent associations, and so perhaps the lack of significance is explained by insufficient power. While small, these associations underscore the importance of factors beyond health care and hospital settings that may affect the emergence and dissemination of antimicrobial resistance. These factors have largely been overlooked by decisionmakers and researchers.

Our empirical analysis has at least five limitations. First, we limited the analysis to three antibiotic-bacterium pairs, as defined by the OECD (14), because of their clinical relevance, prevalence in the literature, and because they are considered priority by the World Health Organization (35). But focusing on only three bacteria limits the generalizability of our findings to antimicrobial resistance more broadly. Second, we examined global literature but then empirically tested findings using data from a single country. While our findings are consistent with existing literature, their external validity could be limited if there were some unobserved idiosyncratic characteristics of Chile driving the results. We currently lack data to test this, but are working with colleagues from other countries in Latin America to generate cross-country data. Third, our panel was not balanced, limiting our ability to use longitudinal panel data analysis strategies. We partially addressed this by controlling for time periods and by using bootstrapping and clustering of standard errors. Fourth, GCRB data are anonymized and we were thus not able to characterize the samples based on the sociodemographic characteristics of patients. We addressed this limitation by characterizing the communities attended by the tertiary hospitals in the dataset based on socioeconomic factors at the municipality level from the CASEN survey. Last, our revision of the literature was limited to PubMed, references cited in selected articles, and our own previous work. Hence, our search may have excluded relevant literature, such as national publications not indexed in PubMed.

Our literature review highlighted that poverty and material deprivation are important risk factors for the emergence and transmission of antimicrobial resistance. Our results were consistent with the literature; we found a negative association between socioeconomic factors (income, education, and occupation) and overall antimicrobial resistance, driven by imipenem and meropenem resistant $P$. aeruginosa and cloxacillin resistant $S$. aureus. These results underscore the need to increase efforts to systematically study risk factors for emergence and spread of antibiotic resistance in humans, including setting-specific factors such as WASH infrastructure or specific industries (e.g., animal protein), and to understand transmission dynamics and interactions across domains (e.g., health care settings, demographics, socioeconomic factors, animal contacts, water sources). More detailed longitudinal cohort studies including public and private health care visits, use of medications, interactions with community members, and economic activities, would be particularly useful; more so if they included various centers across countries to increase external validity of findings. Antimicrobial resistance is a multifactorial public health challenge; researchers and policymakers from the public health community urgently need to pay attention to factors beyond 
nosocomial induced resistance, including poverty reduction, education, and sanitation improvements.

In conclusion, socioeconomic factors beyond health care and hospital settings may affect the emergence and dissemination of antimicrobial resistance. Preventing and controlling antimicrobial resistance requires efforts above and beyond reducing antibiotic consumption.

Author contributions. Study design and analytical methods: KA, PG, JL, JMM, EAU. Data analyses: KA. Manuscript writing (lead): KA, EAU. Data collection (GCRB): PG, JL, JMM, GCRB. Other data collection: KA, MR. Data interpretation, critical manuscript review, edition, final approval: all authors. Secured funding: PG, JL, JMM, EAU. All authors attest they meet the ICMJE criteria for authorship and have reviewed and approved the final manuscript.

Acknowledgments. We thank participants of the Grupo Colaborativo de Resistencia Bacteriana of the Chilean Society of Infectious Diseases for help in data collection and interpretation of results, and Magdalena Letelier, Elisa Piña, Ignacio Irarrázabal, Sylvina Hurtado, Tania Herrera, Johanna Acevedo, Juan Carlos Hormazábal, María Teresa Valenzuela Bravo, José Miguel Bernucci, and María Paz Acuña, for helpful comments and suggestions.

This study is part of a long-term research agenda to study antimicrobial resistance in Chile in close collaboration with the GCRB network and as participants of the Millennium Nucleus for Collaborative Research in Antimicrobial Resistance (MICROB-R). MICROB-R is an interdisciplinary team - including medical doctors, veterinarians, biologists, epidemiologists, economists, and engineers - doing research to understand the mechanisms driving the emergence and dissemination of antimicrobial resistance, evaluate antimicrobial resistance prevention and control programs, and estimate the economic and disease burden of infections in developing countries, to support evidence-based decisions in public health.

Conflicts of interest. The authors declare no conflicts of interest.

Funding. This research was supported by the Millennium Science Initiative of the Ministry of Economy, Development and Tourism, Government of Chile, grant "Millennium Nucleus for Collaborative Research in Antimicrobial Resistance," and Centro UC de Políticas Públicas, from Pontificia Universidad Católica de Chile. The funders of the study had no role in study design, data collection, data analysis, data interpretation, or writing of the report. The corresponding author had full access to all the data in the study and had final responsibility for the decision to submit for publication.

Disclaimer. Authors hold sole responsibility for the views expressed in the manuscript, which may not necessarily reflect the opinion or policy of the RPSP/PAJPH and/or PAHO.

\section{REFERENCES}

1. Laxminarayan $R$, Sridhar D, Blaser M, Wang M, Woolhouse M. Achieving global targets for antimicrobial resistance. Science. 2016;353(6302):874-5.

2. Centers for Disease Control \& Prevention CDC. Antibiotic resistance threats in the United States. Atlanta, GA: US Department of Health and Human Services; 2019 [Available from: https://www.cdc.gov /drugresistance/pdf/threats-report/2019-ar-threats-report-508. pdf. Accessed on February 242019

3. Jee Y, Carlson J, Rafai E, Musonda K, Huong TTG, Daza P, et al. Antimicrobial resistance: a threat to global health. Lancet Infect Dis. 2018;18(9):939-40.

4. Holmes AH, Moore LS, Sundsfjord A, Steinbakk M, Regmi S, Karkey A, et al. Understanding the mechanisms and drivers of antimicrobial resistance. Lancet. 2016;387(10014):176-87.

5. Munita JM, Arias CA. Mechanisms of antibiotic resistance. Microbiol Spectr. 2016;4(2).

6. Chatterjee A, Modarai M, Naylor NR, Boyd SE, Atun R, Barlow J, et al. Quantifying drivers of antibiotic resistance in humans: a systematic review. Lancet Infect Dis. 2018;18(12):e368-78.

7. Klein EY, Van Boeckel TP, Martinez EM, Pant S, Gandra S, Levin $\mathrm{SA}$, et al. Global increase and geographic convergence in antibiotic consumption between 2000 and 2015. Proc Natl Acad Sci. 2018;115(15):E3463-70.

8. Collignon P, Beggs JJ, Walsh TR, Gandra S, Laxminarayan R. Anthropological and socioeconomic factors contributing to global antimicrobial resistance: a univariate and multivariable analysis. Lancet Planet Health. 2018;2(9):e398-405.

9. Kliemann BS, Levin AS, Moura ML, Boszczowski I, Lewis JJ. Socioeconomic determinants of antibiotic consumption in the State of São Paulo, Brazil: The effect of restricting over-the-counter sales. PLoS One. 2016;11(12):e0167885.

10. Malik B, Bhattacharyya S. Antibiotic drug-resistance as a complex system driven by socio-economic growth and antibiotic misuse. Sci Rep. 2019;9(1):9788.
11. Nellums LB, Thompson H, Holmes A, Castro-Sánchez E, Otter JA, Norredam M, et al. Antimicrobial resistance among migrants in Europe: a systematic review and meta-analysis. Lancet Infect Dis. 2018;18(7):796-811.

12. Alividza V, Mariano V, Ahmad R, Charani E, Rawson TM, Holmes $\mathrm{AH}$, et al. Investigating the impact of poverty on colonization and infection with drug-resistant organisms in humans: a systematic review. Infect Dis Poverty. 2018;7(1):76.

13. Roope LSJ, Smith RD, Pouwels KB, Buchanan J, Abel L, Eibich P, et al. The challenge of antimicrobial resistance: What economics can contribute. Science. 2019;364(6435):eaau4679.

14. Organisation for Economic Co-operation and Development OECD. Stemming the Superbug Tide: Just A Few Dollars More. Paris, France: OECD; 2018.

15. Economic Commission for Latin America. Social Panorama of Latin America 2018. Santiago de Chile: Economic Commission for Latin America, United Nations Publications; 2018.

16. Hotez PJ, Bottazzi ME, Franco-Paredes C, Ault SK, Periago MR. The neglected tropical diseases of Latin America and the Caribbean: a review of disease burden and distribution and a roadmap for control and elimination. PLoS Negl Trop Dis. 2008; 2(9):e300.

17. Cifuentes M, Silva F, Arancibia JM, Rosales R, Ajenjo MC, Riedel G, et al. Grupo Colaborativo de Resistencia Bacteriana, Chile: recomendaciones 2014 para el control de la resistencia bacteriana. Rev Chilena Infectol. 2015;32(3):305-18.

18. Clinical and Laboratory Standards Institute. CLSI Performance standards for antimicrobial susceptibility testing; twenty-fourth informational supplement M100-S24 January. Wayne, PA: CLSI; 2014.

19. Bonelli RR, Moreira BM, Picão RC. Antimicrobial resistance among Enterobacteriaceae in South America: history, current dissemination status and associated socioeconomic factors. Drug Resist Updat. $2014 ; 17(1-2): 24-36$. 
20. Okeke IN, Lamikanra A, Edelman R. Socioeconomic and behavioral factors leading to acquired bacterial resistance to antibiotics in developing countries. Emerg Infect Dis. 1999;5(1):18.

21. Nomamiukor BO, Horner C, Kirby A, Hughes GJ. Living conditions are associated with increased antibiotic resistance in community isolates of Escherichia coli. J Antimicrob Chemother. 2015;70(11):3154-8

22. Souza TB, Morais MB, Tahan S, Melli LC, Rodrigues MS, Scaletsky IC. High prevalence of antimicrobial drug-resistant diarrheagenic Escherichia coli in asymptomatic children living in an urban slum. J Infect. 2009;59(4):247-51.

23. Bhutta ZA, Sommerfeld J, Lassi ZS, Salam RA, Das JK. Global burden, distribution, and interventions for infectious diseases of poverty. Infect Dis Poverty. 2014;3(1):21.

24. Kristiansson C, Grape M, Gotuzzo E, Samalvides F, Chauca J, Larsson $\mathrm{M}$, et al. Socioeconomic factors and antibiotic use in relation to antimicrobial resistance in the Amazonian area of Peru. Scand J Infect Dis. 2009;41(4):303-12.

25. Ilić K, Jakovljević E, Škodrić-Trifunović V. Social-economic factors and irrational antibiotic use as reasons for antibiotic resistance of bacteria causing common childhood infections in primary healthcare. Eur J Pediatr. 2012;171(5):767-77.

26. See I, Wesson P, Gualandi N, Dumyati G, Harrison LH, Lesher L, et al. Socioeconomic factors explain racial disparities in invasive community-associated methicillin-resistant Staphylococcus aureus disease rates. Clin Infect Dis. 2017;64(5):597-604.

27. Chokshi A, Sifri Z, Cennimo D, Horng H. Global contributors to antibiotic resistance. J Glob Infect Dis. 2019;11(1):36-42.

28. Seidman JC, Anitha K P, Kanungo R, Bourgeois AL, Coles CL. Risk factors for antibiotic-resistant E. coli in children in a rural area. Epidemiol Infect. 2009;137(6):879-88.

29. Duerink DO, Lestari ES, Hadi U, Nagelkerke NJ, Severin JA, Verbrugh HA, et al. Determinants of carriage of resistant Escherichia coli in the Indonesian population inside and outside hospitals. J Antimicrob Chemother. 2007;60(2):377-84.
30. Egea AL, Gagetti P, Lamberghini R, Faccone D, Lucero C, Vindel A, et al. New patterns of methicillin-resistant Staphylococcus aureus (MRSA) clones, community-associated MRSA genotypes behave like healthcare-associated MRSA genotypes within hospitals, Argentina. Int J Med Microbiol. 2014;304(8):1086-99.

31. Castañeda-Montes F, Avitia M, Sepúlveda-Robles O, CruzSánchez V, Kameyama L, Guarneros G, et al. Population structure of Pseudomonas aeruginosa through a MLST approach and antibiotic resistance profiling of a Mexican clinical collection. Infect Genet Evol. 2018;65:43-54.

32. Bartoloni A, Sennati S, Di Maggio T, Mantella A, Riccobono E, Strohmeyer $\mathrm{M}$, et al. Antimicrobial susceptibility and emerging resistance determinants (blaCTX-M, rmtB, fos A3) in clinical isolates from urinary tract infections in the Bolivian Chaco. Int J Infect Dis. 2016:43:1-6.

33. Young DM, Harris HW, Charlebois ED, Chambers H, Campbell A, Perdreau-Remington F, et al. An epidemic of methicillinresistant Staphylococcus aureus soft tissue infections among medically underserved patients. AMA Arch Surg. 2004;139(9):947-53.

34. Okeke IN. Poverty and root causes of resistance in developing countries. In: Sosa AdJ, Byarugaba DK, Amábile-Cuevas CF, Hsueh P-R, Kariuki S, Okeke IN, editors. Antimicrobial resistance in developing countries: Springer; 2010.

35. World Health Organization. Global priority list of antibioticresistant bacteria to guide research, discovery, and development of new antibiotics Geneva: WHO; 2017 [Available from: https:// www.who.int/medicines/publications/WHO-PPL-Short_Summa ry_25Feb-ET_NM_WHO.pdf. Accessed on February 242019

Manuscript submitted on 30 September 2019. Revised version accepted for publication on 21 February 2020. 


\section{Factores socioeconómicos relacionados con la resistencia a los antimicrobianos de Pseudomona aeruginosa, Staphylococcus aureus y Escherichia coli en hospitales chilenos (2008-2017)}

RESUMEN Objetivo. Determinar los factores socioeconómicos relacionados con la resistencia a los antimicrobianos de Pseudomona aeruginosa, Staphylococcus aureus y Escherichia coli en hospitales chilenos (2008-2017).

Métodos. Se revisó la bibliografía científica acerca de los factores socioeconómicos relacionados con la aparición y el incremento de la resistencia a los antimicrobianos. Mediante una regresión con múltiples variables se examinaron los resultados de la bibliografía respecto a un conjunto de datos longitudinales sobre resistencia a los antimicrobianos de 41 importantes hospitales privados y públicos, así como a una encuesta domiciliaria representativa a nivel nacional en Chile (2008-2017). Se estimaron las tasas de resistencia para tres pares de antibióticos y bacterias prioritarios, de conformidad con lo definido por la Organización de Cooperación y Desarrollo Económicos, es decir: P. aeruginosa, resistente a imipenem y meropenem; $S$. aureus, resistente a cloxacilina y E. coli, resistente a la cefotaxima y ciprofloxacino.

Resultados. La evidencia de la revisión bibliográfica es indicativa de que la pobreza y la privación material suponen importantes factores de riesgo para la aparición y transmisión de la resistencia a los antimicrobianos. La mayoría de los estudios ha demostrado que los peores indicadores socioeconómicos están asociados a mayores tasas de resistencia a los antimicrobianos. Este análisis ha indicado una tasa general de resistencia a los antimicrobianos de $32,5 \%$, con las tasas más elevadas para $S$. aureus $(40,6 \%)$ y las más bajas para E. coli (25,7\%). Se apreció una asociación negativa mínima, aunque uniforme, entre los factores socioeconómicos (ingresos, educación y ocupación) y la resistencia general a los antimicrobianos en un análisis de variable única $(p<0,01)$ y análisis multifactoriales $(p<0,01)$, impulsadas por las bacterias $P$. aeruginosa y $S$. aureus resistentes.

Conclusiones. Los factores socioeconómicos no relacionados con la atención de la salud y los entornos hospitalarios pueden afectar la aparición y la propagación de la resistencia a los antimicrobianos. Su prevención y control precisan esfuerzos adicionales que se sumen a la reducción del consumo de antibióticos.

Palabras clave Farmacorresistencia microbiana; antibacterianos; condiciones sociales; determinantes sociales de la salud; América Latina. 


\section{Fatores socioeconômicos associados à resistência antimicrobiana em Pseudomonas aeruginosa, Staphylococcus aureus e Escherichia coli em hospitais chilenos (2008-2017)}

RESUMO Objetivo. Identificar os fatores socioeconômicos associados à resistência antimicrobiana de Pseudomonas aeruginosa, Staphylococcus aureus e Escherichia coli em hospitais chilenos (2008-2017).

Métodos. Fizemos uma revisão da literatura científica sobre os fatores socioeconômicos associados ao surgimento e à disseminação da resistência antimicrobiana. Usando a regressão multivariada, testamos os resultados da literatura baseando-nos em um conjunto de dados longitudinais sobre a resistência antimicrobiana em 41 grandes hospitais privados e públicos e em uma pesquisa domiciliar representativa da realidade nacional no Chile (2008-2017). Estimamos as taxas de resistência em três pares prioritários de bactérias e antibióticos, como definido pela Organização para a Cooperação e o Desenvolvimento Econômico: P. aeruginosa resistente a imipenem e meropenem, S. aureus resistente a cloxacilina e E. coli resistente a cefotaxima e ciprofloxacino.

Resultados. As evidências desta revisão da literatura sugerem que a pobreza e a privação material são fatores de risco importantes para o surgimento e a transmissão da resistência antimicrobiana. A maior parte dos estudos constatou que piores indicadores socioeconômicos estão associados a taxas mais altas de resistência antimicrobiana. A nossa análise mostrou uma taxa global de resistência antimicrobiana de 32,5\%; S. aureus apresentou as taxas mais altas $(40,6 \%)$ e E. coli as mais baixas (25,7\%). As análises univariadas $(p<0,01)$ e multivariadas $(p<0,01)$ identificaram uma associação negativa pequena, porém consistente, entre fatores socioeconômicos (renda, educação e ocupação) e a resistência antimicrobiana global em P. aeruginosa e S. aureus.

Conclusão. Fatores socioeconômicos, para além dos cuidados de saúde e dos ambientes hospitalares, podem afetar o surgimento e a disseminação da resistência antimicrobiana. Para prevenir e controlar esta resistência, é preciso fazer esforços que não se limitem à redução do consumo de antibióticos.

Palavras-chave Resistência microbiana a medicamentos; antibacterianos; condições sociais; determinantes sociais da saúde; América Latina. 